\title{
A new concept of three-dimensional study of fiction at the university
}

\author{
Zukhra A. Kuchukova ${ }^{1 *}$, Liana B. Berberova ${ }^{2}$, and Burkhan A. Berberov ${ }^{3}$ \\ ${ }^{1}$ Kabardino-Balkarian State University named after Kh.M. Berbekov, Russian and Foreign Literature \\ Department, Nalchik, Russia \\ ${ }^{2}$ Financial University under the Government of the Russian Federation, English Language and \\ Professional Communication Department, Moscow, Russia \\ ${ }^{3}$ Institute for Humanitarian Studies, Branch of the Federal Research Center, "Kabardino-Balkarian \\ Research Center of the Russian Academy of Sciences" (IHR KBSC RAS), Nalchik, Russia
}

\begin{abstract}
The relevance of the study is due to the need to modernize the methodology of teaching literature in Russian regional universities, taking into account the current processes of globalization. The proposed method is conventionally called "Three flanks", and provides for the study of national literature in close correlation with classical Russian and foreign literature. From the pedagogical standpoint, the system-synergetic approach is especially important for a multiethnic region, such as the North Caucasus. The purpose of the article is to substantiate the expediency and effectiveness of the comparative method of studying fiction and to propose a threedimensional model, which is currently being tested at the framework of a special course at the Faculty of Philology of Kabardino-Balkarian State University. The authors used comparative-historical, system-structural, and axiological methods of scientific analysis. In order to harmonize the multicultural material, logical principles of analysis were used, namely, classification, typology, generalization, as well as the method of continuous sampling to identify representative texts. The article presents a pedagogical experiment that is currently being conducted in one of the North Caucasus universities. The essence of the experiment is a comparative study of national literature at the level of comparisons with world literature.
\end{abstract}

Keywords: national literature, a three-dimensional study, the accelerated development, up-to-date matrices.

\section{Introduction}

The processes associated with globalization gradually accustom enlightened people to the absurdity of studying national literature, taken out of the context of world culture. In this regard, the title of K. Sultanov's monograph "From Home to the World" [1] is gradually becoming a guideline for action for many teachers of Russian literature. People give a new meaning to the words of O. Suleimenov that "there is no West and no East, but only sunrise

\footnotetext{
* Corresponding author: kuchuk60@list.ru
} 
and sunset" [2], which indicates the commonality of human thinking and the unity of historical roots in culture.

\section{Diachrony: the idea of repetitiveness}

From this standpoint, the authors consider it appropriate to begin studying any national literature from the diachronic perspective, addressing the mythological dictionaries, where "myth-making is regarded as the most important event in the cultural history of mankind", and "the cosmic space is represented by a living giant, from the parts of which the world is created" [3: 12].

Before the emergence of the Internet, in the era of "Chinese walls" and "iron curtains", each ethnic culture was thought of as autonomous, unique, and inimitable both in general and in its structural components. In the preface to almost every collection of national fairy tales, the authors considered it appropriate to emphasize that the Russian (Ukrainian, Armenian, Uzbek, or any other) fairy tale is original and unique in its kind.

In the proposed new (still hypothetical) textbook on national literature, immediately after getting acquainted with the key mythological motives, a section should be presented about the oldest folklore monument Panchatantra (the Pentateuch, meaning five books), created in the third century AD in Sanskrit, which is the officially recognized proto-language of mankind.

According to literary historians, this book has an unusual creative fate, because the oldest monument itself has not been preserved, but, fortunately, it was translated into national language by Arab scriptwriters, in particular, Ibn al-Muqaffa, who was said to be "more than a translator, but less than an author" [4: 5]. The Arabic version of the Panchatantra has reached today's reader under the name "Kalila and Dimna" [4]. Its genre composition is determined by fairy tales, fables, and parables.

The authors of the present article have many times witnessed the "cultural revolution" that took place in the minds of students who were convinced that ever since the year dot, long before the birth of today's ethnic communities and national fairy tales, the first seeds of world culture were already reflected in "Kalila and Dimna" (and several other ancient sources).

The founders of the migration theory [5: 58] tracked the movement of the folklore archetypes of Panchatantra around the globe, which gradually settled and took root in the folklore of different peoples. It should be noted that earlier in the pre-Internet period, specialists had to read entire libraries to track the folklore logistics of the storyline. This was the only way to catch this or that "migratory seed" from Ancient India, which turned out to be in the popular ethnographic tale of today. In the 21st century, today's students can type the name or motive of a folklore text from "Kalila and Dimna" in any search engine to find its genetic relatives in fairy tales, parables, and fables of different peoples of the world immediately.

The folklore texts that reached today's bookshelves and Internet sites from the oldest Indian-Arabic "chest" include "The Lion and the Mouse", "The Story of a Raccoon", "RikkiTikki-Tavi", "The Fox and the Crane", "The Frog-Traveler", "The Three Brothers", "The Greedy Dog", "The Monkey and the Turtle", etc. Naturally, the introduction of archetypes into the new culture occurred through national adaptation, which "brings the text closer to the literature and to the environment where its second life begins from now on" [6: 43]. The analysis shows that adaptation is mainly carried out through translation, stylization, compression, and fictionalization.

The method of national adaptation, first of all, involves the transformation of the subject world, the "interior" of the fairy tale, so that the consciousness of the new reader does not reject the foreign-cultural text. Here is a simple example. In the Indian-Arabic primary source, there is a fairy tale called "The Tortoise and the Ducks". The classic of Russian 
literature, V. Garshin, in the artistic treatment of the oldest plot, deliberately changed the exotic image of a tortoise to a frog - an image that was emotionally close to the Slavic mentality.

For the students to feel the depth of their historical and cultural roots, during one of the lessons they are recommended to correlate the world of their native fairy tales with the folklore content of the Panchatantra and take a detailed look at the migration, transcultural path of several texts.

Students should be told about the Finnish scientists A. Aarne and S. Thompson, who created a catalog of fairy-tale plots and motives "The Types of International Folktales". At a certain stage of the civilization's development, humanity needs to record in writing the "clots of thought" accumulated by the collective mind. This need has resulted in the emergence of all sorts of encyclopedias, dictionaries of symbols, and literary archetypes. Their highest meaning lies in the formation of a "mobilized person" [7: 132], who can receive a guiding line for overcoming chaos in the spiritual space in any challenging situation.

\section{Synchrony: up-to-date matrices}

The law of archetypes recurrence is valid in world literature not only in historical vertical but also geographic horizontal. In this context, when studying the national literature one should base on the theory of the Russian philosopher G. Gachev about the accelerated development of literature, according to which "many peoples of Eastern Europe, the Soviet and foreign East, Africa, and Latin America, who have been delayed due to various reasons in their development, at a certain moment, join a single world-historical process and move forward in a short time, catching up, and in some ways surpassing other countries, peoples, and cultures" [8: 4].

Supporting and developing Gachev's theory, it should be noted that the literary noosphere, which encircles the entire globe, tends to align as if obeying the law of communicating vessels. Word-painters have always had a tendency to learn from each other, which is why there is so much in common between "Childe Harold's Pilgrimage" by G. Byron and "Eugene Onegin" by A. Pushkin, between "Madame Bovary" by G. Flaubert and "Anna Karenina" by L. Tolstoy. This list can be continued, but its essence comes down to the fact that at one or another historical juncture, "up-to-date matrices" appear in the global world, which each interested literary artist fills with subjective content, depending on the political regime, ethnic mentality, and their own talent.

Before the emergence of Internet technologies, one of the main catalysts for the accelerated development of national literature was the art of literary translation. At the beginning of the 20th century, every Caucasian writer was also engaged in the practice of translation, transferring the works of foreign and Russian classics to their own ethnic culture. During this intense period, not only texts were translated but also genres, and styles, literary trends, innovative for this region.

The authors of the present article conducted a special study of the creative works of Kaisyn Kuliev ${ }^{\dagger}$ in terms of mastering the main areas of world culture. It turned out that the Balkar "stormy genius" in his literary practice passed the schools of the ancient hexameter, Renaissance anthropocentrism, ordered classicism, excessive Baroque, delicate sentimentalism, romantic duality, and reflection of existentialism, i.e., the entire short course of world literature.

Kuliev's "Mountain Ballad" is a vivid example of the transformation of a Scottish ballad into the Balkar poetic world through the Russian ballad aesthetics, especially through the ballads of N. Tikhonov. In his autobiographical book "And Tree is Growing So", Kuliev

\footnotetext{
${ }^{\dagger}$ Soviet Balkar poet and prose writer
} 
writes: "What an accurate verse in Tikhonov's ballads! Wonderful laconism. Each line is like a blade strike" [9: 137]. Paying tribute to his teacher, Kuliev ends "Mountain Ballad" with a quatrain:

\author{
Don't whip a good horse ... \\ A ballad, if in rhythm \\ I spurred you on, come on - \\ Let Tikhonov forgive me! [10: 69]
}

Here one observes the literary technique called name-dropping. Revealing the essence of the term, contemporary scientists note that "the reference to known names erases time boundaries; the axiological orientation when using different names and titles creates a new spatiotemporal unity" [11: 199]. In other words, the mere mention of Tikhonov's name immediately emphasizes the intertextual connection of the Balkar ballad with the ballad traditions of Russian authors.

A three-dimensional study of literature (national - Russian - foreign) shows the potential of up-to-date matrices, which in diverse cultures while maintaining their ontological core, are filled with ethnically labeled material. A striking example is three typologically similar works - "One Hundred Years of Solitude" by G.G. Marquez [12], "Farewell to Matera" by V. Rasputin [13], and "A Worldwide Flood" by M. Emkuzhev [14]. The Columbian, the Russian, and the Kabardian writers base their texts on a single archetype related to environmental issues: the aggressive attitude of humans to nature turns into a universal catastrophe. But at the same time, each of them, putting this philosophical idea in an artistic image, refers to the ethnopoetic constants of their own ethnos. Each has its style pattern when describing the image of the landscape, the national logos, and the spiritual order.

When compiling an ideal textbook on national literature, in the authors' opinion, a special section should be devoted to the creative work of bilingual writers. The artistic practice of Russophonic North Caucasian writers (B. Chipchikov, M. Emkuzhev, A. Makoev, J. Koshubaev, R. Kuchmezova) can become a vivid illustration of the process where the text from an individual cultural unit "turns into a zone of "cross-pollination" with multiple meanings, into a creative field with an increased potential toward generating new images of the world" [15: 354].

\title{
4 Conclusion
}

1. The processes associated with globalization require revising the previous methodological guidelines at all educational levels. The new concept of teaching literature in Russian universities is seen as a three-dimensional model, which provides for the comparative study of national, Russian, and foreign literature in an organic unity, and in a logical sequence from the particular to the general.

2. In order to form historical consciousness in students, it is recommended to start studying native literature with archaic primary sources ("Panchatantra", "Kalila and Dimna"), demonstrating the planetary commonality of human culture. The idea of the continuity of spiritual values is supported by the study of archetypes, symbols, mythologies, and concepts in a diachronic context.

3. The horizontal-synchronic study of world literature based on the identification of up-todate matrices that have become the basis for typologically similar creative works of Balkar, Russian, and foreign authors is of great educational and upbringing importance. The effect of accelerated development, described by Gachev in the middle of the 20th century, is further intensified in the era of Internet technologies, having been crowned by the globalization of art culture. 


\section{References}

1. K.K. Sultanov, Ot doma k miru: etnonatsionalnaya identichnost' v literature i mezhkul'turnyi dialog [From Home to the World: Ethnonation. identity in literature and intercultural dialogue] (Institute of World Literature n.a. A.M. Gorky RAS, Nauka, Moscow, 2007)

2. V. Krupin, Net Vostoka i Zapada, yest' voskhod i zakat [There is no West and no East, but only sunrise and sunset]. Accessed on: December 20, 2020. [Online] Available: https://zyorna.ru/news/retsenzii/net-vostoka-i-zapada-est-voshod-i-zakat-3432.html

3. S.A. Tokarev (ed.), Mify narodov mira [Myths of the peoples of the world], Volume 1. (Sovetskaya entsiklopediya, Moscow, 1991)

4. A. ibn al-Muqaffa, Kalila and Demna (Khudozhestvennaya literatura, Moscow, 1986)

5. A.N. Nikolyukin (ed.), Literaturnaya entsiklopediya terminov i ponyatiy [Literary encyclopedia of terms and concepts] (Institute of Scientific information on social sciences RAS, Intelvak, Moscow, 2003)

6. L.Ye. Cherkassky, Russkaya literatura na Vostoke. Teoriya i praktika perevoda [Russian literature in the East. Theory and practice of translation] (Nauka, Moscow, 1987)

7. H.G. Tkhagapsoev, Kul'turologicheskaya nauka na paradigmal'nykh razlomakh [Cultural science on paradigmatic fissures] (Publishing house of the Russian State Pedagogical University n.a. A.I. Herzen, Saint-Petersburg, 2019)

8. G.D. Gachev, Neminuyemoye. Uskorennoye razvitiye literatury [Inevitable. Accelerated development of literature] (Khudozhestvennaya literatura, Moscow, 1989)

9. K. Kuliev, Tak rastet i derevo [And tree is growing so] (Sovremennik, Moscow, 1975)

10. K. Kuliev, Gornaya ballada [Mountain ballad], in Sobranie sochineniy v trekh tomakh [The collected works in three volumes]. Volume 1, 67-69 (Khudozhestvennaya literatura, Moscow, 1976)

11. M.L. Novikova, F.N. Novikov, Filologicheskiye nauki, 6(2), 194-204 (2020)

12. G. G. Marquez, One hundred years of solitude (Penguin, Londin, 2012)

13. V.G. Rasputin, Proshchanie s Materoi [Farewell to Matera] (Azbuka, Moscow, 2019)

14. M.Kh. Emkuzhev, Vsemirnyy potop [A Worldwide Flood] (Elbrus, Nalchik, 1994)

15. O.A. Valikova, A.S. Demchenko, Polilingvialnost i Transkulturnye Praktiki, 17(3), 352-362 (2020). https://doi.org/10.22363/2618-897X-2020-17-3-352-362 